\title{
PENERAPAN METODE PROBLEM SOLVING UNTUK MENINGKATKAN HASIL BELAJAR PENDIDIKAN AGAMA ISLAM DI SDN 07 INDRALAYA UTARA
}

\author{
Junaidah \\ Guru Sekolah Dasar Negeri 07 Indralaya Utara \\ Jalan Andalas Desa Parit, Kecamatan Indralaya Utara \\ Kabupaten Ogan Ilir, Sumatera Selatan 30662
}

\section{Sur-el: mirjunaidah2@gmail.com}

Article info

Article history:

Received:03-03-2020

Revised :24-03-2020

Accepted:04-05-2020

Keywords:

Problem Solving

Method, Pendidikan

Agama Islam,

Learning Outcomes

Kata Kunci:

Metode Problem

Solving, Pendidikan

Agama Islam, Hasil

Belajar

\begin{abstract}
A B S T R A C T
This study aims to determine the improvement of student learning outcomes in Pendidikan Agama Islam subjects by applying the Problem Solving method. The research was conducted in Semester Ganjil 2019. This research was a Classroom Action Research (CAR which consisted of two cycles. Subjects in this study were sixth grade students of SD Negeri 07 Indralaya Utara, totaling 21 students. Data collection techniques used were observation and The results showed that in the first cycle, $66.67 \%$ of students obtained mastery learning in KKM 70. In Cycle II, mastery learning increased to $90.4 \%$ of students who achieved KKM 70. So, it can be concluded that learning using the Problem method Solving can improve student learning outcomes in Pendidikan Agama Islam subjects.
\end{abstract}

Penelitian ini bertujuan untuk mengetahui peningkatkan hasil belajar siswa pada mata pelajaran Pendidikan Agama Islam dengan menerapkan metode Problem Solving. Pelaksanaan penelitian ini dilakukan pada semester Ganjil 2019. Penelitian ini merupakan Penelitian Tindakan Kelas (PTK yang terdiri dari dua siklus. Subjek dalam penelitian ini adalah siswa kelas VI SD Negeri 07 Indralaya Utara yang berjumlah 21 orang siswa. Teknik pengumpulan data yang digunakan adalah pengamatan dan tes. Hasil penelitian menunjukkan bahwa pada siklus I, 66,67\% siswa memperoleh ketuntasan belajar pada KKM 70. Pada Siklus II, ketuntasan belajar meningkat menjadi 90,4\% siswa yang mencapai KKM 70. Jadi, dapat disimpulkan bahwa pembelajaran dengan menggunakan metode Problem Solving dapat meningkatkan hasil belajar siswa pada mata pelajaran Pendidikan Agama Islam. 


\section{JURNAL ILMIAH \\ BINA EDUKASI \\ ISSN 1979-8598 E-ISSN: 2655-8378 \\ http://journal.binadarma.ac.id/index.php/jurnalbinaedukasi \\ Vol. 13, No. 1, Juni 2020, 41 -- 51}

\section{PENDAHULUAN}

Pendidikan adalah suatu usaha membina kepribadian manusia, pembinaan merupakan pengaruh secara sadar ditujukan kepada pribadi, sehingga terbentuk akhlak yang baik. Sementara itu, Tafsir (1992) mengatakan bahwa "pendidikan merupakan usaha meningkatkan diri dalam segala aspek-aspeknya. Definisi ini mencakup kegiatan pendidikan yang melibatkan guru atau tidak melibatkan guru dalam membina akhlak siswa. Keberadaan guru agama sangat penting tidak hanya mengajarkan ilmu pengetahuan kepada siswa tetapi membina akhlak siswa juga menjadi perhatian guru agama. Adapun peranan guru agama meliputi: membiasakan budaya salam di dalam pergaulan antara siswa dan guru, membiasakan siswa untuk berdoa sebelum memulai suatu pekerjaan sehingga apa yang akan dikerjakan akan mendapat ridho dari Allah Swt. menumbuhkan rasa toleransi di dalam diri siswa, menumbuhkan rasa sosial di dalam diri siswa dengan cara ikut berpartisipasi di dalam memberikan bantuan dan membersihkan lingkungan sekolah dan menumbuhkan budaya bersih di dalam diri siswa baik itu menjaga kebersihan diri maupun kebersihan lingkungan, semuanya termasuk akhlak mahmudah.

Proses pembelajaran yang efektif dapat memberikan hasil belajar yang baik. Jika proses belajar mengajar tidak optimal maka sulit untuk mencapai hasil belajar yang baik. Untuk mengukur keberhasilan siswa dalam mencapai tujuan pembelajaran yang telah ditetapkan dilakukan evaluasi. Hamalik (2007) mengemukakan bahwa evaluasi hasil belajar merupakan keseluruhan pengukuran untuk membuat keputusan tentang tingkat hasil belajar siswa setelah melakukan kegiatan belajar mengajar.

Dari hasil penilaian awal di kelas VI pada mata pelajaran PAI diketahui bahwa nilai ratarata kelas belum mencapai ketuntasan sesuai Kriteria Ketuntasan Minimal (KKM) yakni 70 dengan target persentase ketuntasan $75 \%$. Berdasarkan nilai prasiklus pada mata pelajaran PAI di kelas VI diperoleh data, yaitu sebesar 38,09\% atau 8 siswa yang mencapai KKM 70 sedangkan 61,90\% atau 13 siswa belum tuntas. Berdasarkan hal tersebut, peneliti melakukan upaya untuk meningkatkan hasil belajar siswa dengan menerapkan metode problem solving pada mata pelajaran Pendidikan Agama Islam. Saat menerapkan metode tersebut, materi yang digunakan dalam kegiatan belajar mengajar adalah "Menghindari Perilaku Tercela". Dalam penerapannya, penelitian ini diharapkan agar pembelajaran lebih bermakna bagi siswa sehingga akan memberikan pengaruh terhadap peningkatan hasil belajar siswa.

Metode problem solving adalah metode pembelajaran yang dapat diterapkan untuk melatih siswa menghadapi berbagai masalah, baik masalah pribadi atau individu maupun masalah kelompok untuk dipecahkan sendiri atau secara bersama-sama (Muhtar dalam Misbahudin, 2018). Misbahudin (2018) mendefinisikan metode problem solving sebagai cara memberikan pengertian 


\section{JURNAL ILMIAH \\ BINA EDUKASI \\ ISSN 1979-8598 E-ISSN: 2655-8378 \\ http://journal.binadarma.ac.id/index.php/jurnalbinaedukasi \\ Vol. 13, No. 1, Juni 2020, 41 -- 51}

dengan menstimulasikan anak didik untuk memperhatikan, menelaah dan berpikir tentang suatu masalah untuk selanjutnya menganalisis masalah tersebut untuk memecahkan masalah.

Selain alasan tersebut, peneliti tertarik menggunakan metode problem solving dalam kegiatan belajar PAI karena terinspirasi dari hasil penelitian-penelitian yang serupa. Adapun penelitian-penelitian terdahulu yang membahas tentang metode problem solving adalah sebagai berikut.

Pertama, Luqoni (2018) melakukan penelitian dengan judul "Penerapan Metode Problem Solving untuk Meningkatkan Kompetensi Hasil Belajar Siswa pada Mata Pelajaran Fiqih di MtsN Pesanggaran Kabupaten Banyuwangi" dengan hasil yang menunjukkan bahwa kompetensi hasil belajar siswa pada mata pelajaran Fiqih mengalami peningkatan yang bagus dan memuaskan. Peningkatan hasil belajar terlihat dari berbagai aspek belajar, yaitu kognitif, afektif, dan psikomotorik.

Kedua, Apriadin (2018) juga melakukan penelitian serupa dengan judul "Penerapan Metode Problem Solving dalam Belajar Siswa Kelas VI pada Mata Pelajaran Fiqih di MI NW Dasan Agung Mataram". Hasil penelitian tersebut adalah 1) penerapan metode problem solving membantu siswa mengatasi kesulitan belajar karena metode ini membuat siswa menjadi lebih aktif dalam memecahkan masalah yang diberikan guru. Siswa juga menjadi lebih kreatif dan bertanggung jawab dalam memecahkan suatu masalah; 2) kendala yang dialami siswa di MI Mataran adalah kesulitan memahami penjelasan guru.

Ketiga, Maftuhatun (2016) juga melakukan penelitian serupa dengan subjek siswa SD yang berjudul "Metode Problem Solving dalam Pembelajaran PAI di SD Muhammadiyah Demangan Yogyakarta". Dari hasil penelitian diketahui bahwa penerapan metode problem solving dalam pelajaran PAI dilaksanakan dalam beberapa langkah, yaiti mengidentifikasi masalah, menegaskan masalah, memilih strategi pemecahan masalah, melaksanakan strategi yang dipilih, dan melakukan evaluasi hasil.

Berdasarkan uraian latar belakang tersebut maka rumusan masalah dalam penelitian ini adalah "bagaimana penerapan metode problem solving untuk meningkatkan hasil belajar Pendidikan Agama Islam pada siswa kelas VI SDN 07 Indralaya Utara?”. Adapun tujuan dalam penelitian ini adalah untuk mengetahui penerapan metode problem solving untuk meningkatkan hasil belajar Pendidikan Agama Islam melalui pada siswa kelas VI SDN 07 Indralaya Utara. Manfaat hasil penelitian ini adalah dapat meningkatkan hasil belajar siswa pada mata pelajaran Pendidikan Agama Islam dan perbaikan pembelajaran menggunakan metode problem solving. 


\section{JURNAL ILMIAH \\ BINA EDUKASI \\ ISSN 1979-8598 E-ISSN: 2655-8378 \\ http://journal.binadarma.ac.id/index.php/jurnalbinaedukasi \\ Vol. 13, No. 1, Juni 2020, 41 -- 51}

\section{METODOLOGI PENELITIAN}

\subsection{Problem Solving}

Rahim (2001) mendefinisikan metode problem solving (metode pemecahan masalah) sebagai metode pembelajaran yang digunakan untuk merangsang pelajar berpikir. Karenanya, metode ini akan banyak memanfaatkan metode-metode lain yang dimulai dari pencarian data sampai kepada penarikan kesimpulan. Selain itu, metode ini juga akan melibatkan banyak kegiatan dengan bimbingan dari guru kepada siswa. Adapun langkah-langkah metode pembelajaran problem solving sebagai berikut.

a) Guru mengidentifikasi masalah dengan jelas untuk diselesaikan atau dipecahkan. Masalah ini harus berkembang dari siswa sesuai dengan tingkat kemampuannya.

b) Siswa dapat mencari data atau keterangan yang digunakan untuk memecahkan masalah tersebut. Contohnya, dengan bertanya, berdiskusi, membaca buku, atau melakukan penelitian, dan lain-lain.

c) Siswa dapat menentukan jawaban sementara (hipotesis) terhadap masalah tersebut berdasarkan data yang telah diperoleh pada langkah kedua.

d) Siswa menguji kebenaran jawaban sementara yang telah dirumuskan sebelumnya. Pada langkah ini, siswa berusaha untuk dapat memecahkan masalah sehingga betul-betul yakin akan kebenaran jawaban tersebut itu. Pengujian kebenaran jawaban ini membutuhkan metode-metode lain seperti demonstrasi, tugas, dan diskusi.

e) Siswa menarik kesimpulan dari pemecahan masalah yang dilakukan atau menemukan solusi. Artinya, siswa harus sampai kepada kesimpulan terakhir tentang jawaban dari masalah.

\subsection{Jenis Penelitian}

Adapun jenis penelitian yang dilakukan oleh peneliti adalah Penelitian Tindakan Kelas (PTK). PTK ini juga disebut sebagai Classroom Active Research (CAR). Menurut Aqib (2009), penelitian tindakan kelas adalah kegiatan mencermati suatu objek dengan menggunakan serangkaian cara tertentu untuk mendapatkan data atau informasi yang bermanfaat untuk meningkatkan mutu dari suatu hal melalui suatu kegiatan yang sengaja dilakukan dengan maksud tertentu pada sekelompok siswa di kelas saat kegiatan belajar mengajar sedang berlangsung. Menurut Sukardi (2007), PTK memiliki beberapa ciri khas, yaitu sebagai berikut.

a. Masalah yang diteliti adalahan masalah kegiatan belajar mengajar yang dihadapi peneliti di kelas.

b. Peneliti menerapkan perlakuan yang terencana untuk memecahkan permasalahan tersebut.

c. Langkah-langkah penelitian yang direncanakan tersusun dalam sebuah siklus atau tingkatan yang memungkinkan terjadi kerja kelompok maupun kerja mandiri secara intensif. 


\section{JURNAL ILMIAH}

BINA EDUKASI

ISSN 1979-8598 E-ISSN: 2655-8378

http://journal.binadarma.ac.id/index.php/jurnalbinaedukasi

Vol. 13, No. 1, Juni 2020, 41 -- 51

d. Peneliti melakukan langkah berpikir reflektif, baik sesudah maupun sebelum tindakan.

Serupa dengan Sukardi, Soedarsono (2001) lebih dulu mengemukakan karakteristik PTK sebagai berikut.

a) situasional, maksudnya berkaitan langsung dengan permasalahan konkret yang dihadapi guru dan siswa di kelas;

b) kontekstual, maksudnya upaya pemecahan yang berupa model dan prosedur tindakan tidak lepas dari konteksnya;

c) kolaboratif, maksudnya partisipasi antara guru—siswa dan mungkin asisten yang membantu proses pembelajaran;

d) self-reflective dan self-evaluative, maksudnya pelaksana, pelaku tindakan serta objek yang dikenai tindakan melakukan refleksi dan evaluasi diri terhadap hasil atau kemajuan yang dicapai; dan

e) fleksibel, artinya memberikan sedikit kelonggaran dalam pelaksanaan tanpa melanggar kaidah metodologi ilmiah.

Penelitian Tindakan Kelas ini menggunakan alur penelitian yang dikembangkan oleh Elliot (dikutip Atmono, 2009) yang bermanfaat untuk mengidentifikasi perkembangan dan perubahan subjek setelah diberikan perlakuan khusus atau dikondisi tertentu dalam kurun waktu tertentu dan berulang-ulang sampai program atau metide dinyatakan berhasil. Model Elliot ini dapat dilakukan dalam beberapa siklus. Setiap siklus terdiri dari empat tahapan, yaitu: (a) perencanaan (Planning), (b) pelaksanaan tindakan (action), (c) pengamatan (observasi), dan (d) refleksi, (reflection). Berikut ini merupakan alur PTK Model Elliot.

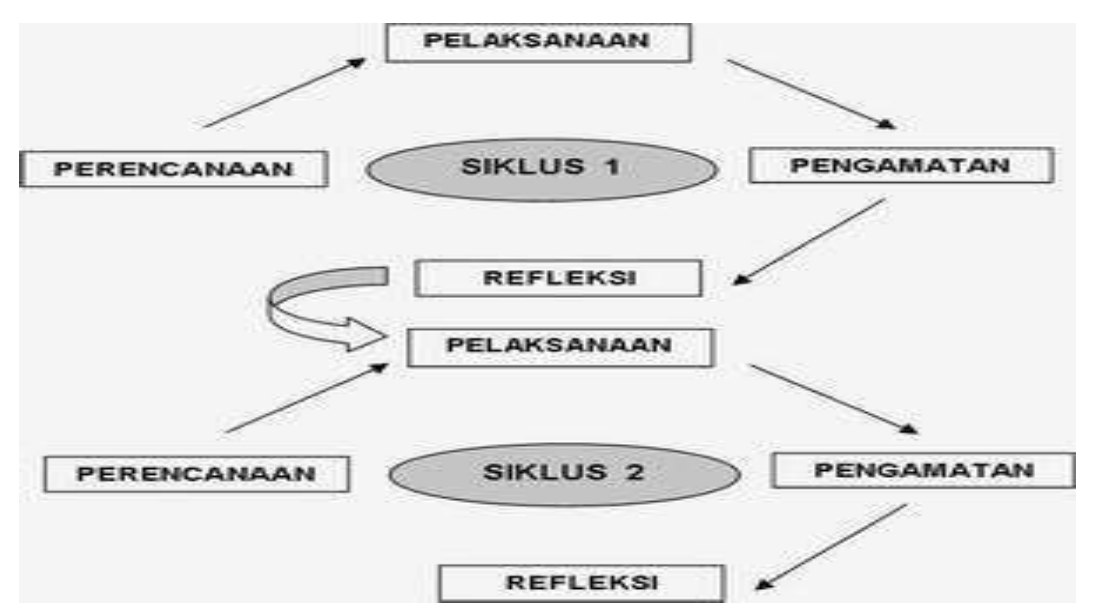

Gambar 1. Alur Penelitian Tindakan Kelas Model Elliot 


\section{JURNAL ILMIAH}

BINA EDUKASI

ISSN 1979-8598 E-ISSN: 2655-8378

http://journal.binadarma.ac.id/index.php/jurnalbinaedukasi

Vol. 13, No. 1, Juni 2020, 41 -- 51

\subsection{Subjek Penelitian}

Kegiatan PTK ini dilakukan di SDN 07 Indralaya Utara yang beralamat di Jalan Andalas Desa Parit Kecamatan Indralaya Utara Kabupaten Ogan Ilir Provinsi Sumatera Selatan. Adapun subjek penelitian ini adalah siswa kelas VI SDN 07 Indralaya Utara yang berjumlah 21 orang. Terdiri dari 9 siswa laki-laki dan 12 siswa perempuan.

\subsection{Teknik Pengumpulan Data}

Data dalam penelitian ini merupakan deskripsi kondisi dan situasi kegiatan pembelajaran di kelas dan nilai tes siswa pada mata pelajaran PAI, khusunya materi "Menghindari Perilaku Tercela". Teknik pengumpulan data yang digunakan sebagai berikut.

a) Lembar observasi, yaitu data dikumpulkan dengan cara mengamati proses pembelajaran siswa selama proses pembelajaran dengan menggunakan pembelajaran metode problem solving.

b) Tes. Tes digunakan untuk mengumpulkan data tentang hasil belajar siswa setelah proses pembelajaran dengan model pembelajaran metode problem solving. Tes yang digunakan oleh peneliti adalah tes tertulis dalam bentuk uraian berdasarkan materi yang diajarkan. Tes diberikan sebanyak tiga kali, yaitu: tes prasiklus, postes siklus I, dan postes siklus II.

Hasil penelitian diperoleh dengan menganalisis hasil observasi dan tes yang telah dikumpulkan untuk mengukur hasil belajar siswa pada mata pelajaran PAI menggunakan metode problem solving. Data dari hasil tes diolah menggunakan rumus teknik proporsi (Sudjana, 2010:17) berikut.

$$
D=\frac{A}{N} \times 100 \%
$$

Keterangan:

D: Persentase siswa yang tuntas

A: Jumlah siswa yang tuntas

$\mathrm{N}$ : Jumlah seluruh siswa

Pengolahan data tes diawali dengan kegiatan penskoran. Penskoran dilakukan terhadap jawaban tes siswa. Penghitungan skor menggunakan rumus berikut.

$$
D=\frac{X}{N} \times 100 \%
$$

Keterangan:

D : Persentase hasil belajar siswa

$\mathrm{X}$ : Jumlah siswa yang Tuntas

$\mathrm{N}$ : Jumlah seluruh siswa 


\section{JURNAL ILMIAH}

BINA EDUKASI

ISSN 1979-8598 E-ISSN: 2655-8378

http://journal.binadarma.ac.id/index.php/jurnalbinaedukasi

Vol. 13, No. 1, Juni 2020, 41 -- 51

Indikator keberhasilan dalam penelitian ini adalah jika $\leq 75 \%$ siswa kelas VI SDN 07 Indralaya Utara memperoleh nilai $\leq K K M 70$ untuk materi yang diajarkan. Persentase keberhasilan pencapaian hasil belajar siswa ditentukan berdasarkan acuan dari Fatimah (2008) berikut.

Tabel 1. Persentase Keberhasilan Pencapaian Hasil Belajar Siswa

\begin{tabular}{lll}
\hline No & \multicolumn{1}{c}{ Persentase Ketuntasan } & \multicolumn{1}{c}{ Katagori } \\
\hline 1 & $\ldots \ldots . . \geq 80 \%$ & Sangat tinggi \\
2 & $70 \%-79 \%$ & Tinggi \\
3 & $60 \%-69 \%$ & Cukup \\
4 & $50 \%-59 \%$ & Kurang \\
5 & $\ldots \ldots \leq 49$ & Sangat kurang \\
\hline
\end{tabular}

Peneliti menetapkan 75\% tercapai KKM 70 sebagai indikator keberhasilan pada PTK ini dengan judul "Penerapan Metode Problem Solving untuk Meningkatkan Hasil Belajar Pendidikan Agama Islam di Kelas VI SDN 07 Indralaya Utara ”.

Hasil analisis data disajikan dalam bentuk grafik dan tabel untuk memudahkan pembacaan dan pemahaman hasil penelitian sehingga dapat memprediksi penarikan kesimpulan dari penelitian yang dilakukan.

\section{HASIL DAN PEMBAHASAN}

Hasil tes disajikan dalam bentuk data kuantitatif sedangkan hasil pengamatan disajikan dalam bentuk deskriptif. Penelitian ini bertujuan untuk meningkatkan motivasi dan hasil belajar siswa dengan penerapan metode problem solving.

\subsection{Hasil}

Berikut ini merupakan persentase peningkatan hasil belajar siswa pada mata pelajaran PAI dari persentase nilai akhir tes prasiklus, postest siklus I, dan postest siklus II.

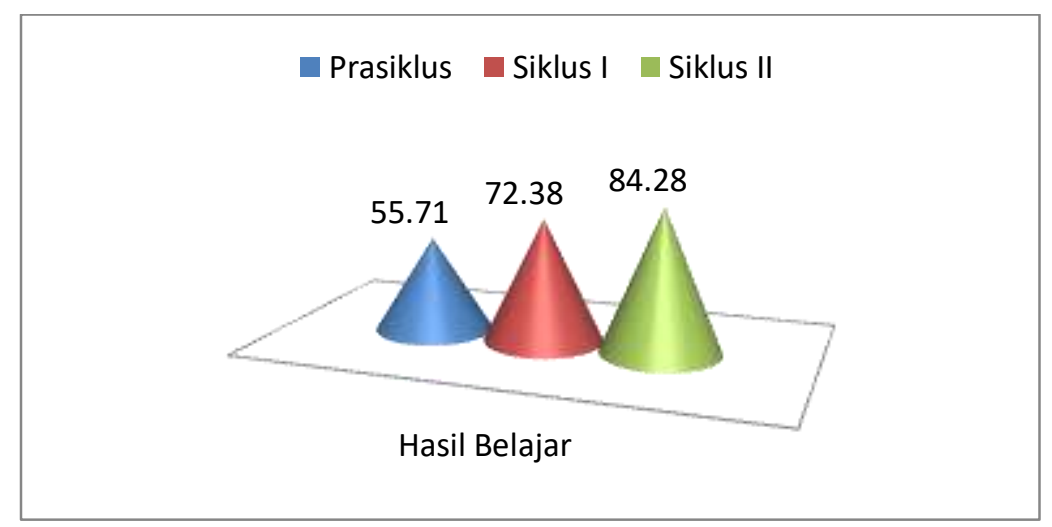

Gambar 2. Bagan Persentase Hasil Belajar Siswa 


\section{JURNAL ILMIAH \\ BINA EDUKASI \\ ISSN 1979-8598 E-ISSN: 2655-8378 \\ http://journal.binadarma.ac.id/index.php/jurnalbinaedukasi \\ Vol. 13, No. 1, Juni 2020, 41 -- 51}

Dari keterangan bagan di atas dapat diketahui bahwa hasil belajar siswa Kelas VI SDN 07 Indralaya Utara pada Mata Pelajaran PAI mengalami peningkatan setelah menerapkan metode problem solving. Pada bagan tersebut terlihat bahwa ada peningkatan persentasen nilai rata-rata kelas yang signifikan dari prasiklus ke postes siklus I, yaitu sebesar 16,67\% dari 55,71\% ke 72,38\%. Dari hasil belajar Siklus I, indikator ketuntasan yang ditetapkan belum tercapai maka dilanjutkan ke siklus II. Dari hasil belajar pasa siklus I, yaitu 72,30\% meningkat sebesar 11,98\% di hasil belajar pada siklus II, yaitu sebesar $84,28 \%$.

Keefektifan penerapan diskusi dalam peningkatan hasil belajar yang terlihat dari Pra Siklus, Siklus I dan Siklus II. Penelitian ini dicukupkan pada Siklus II karena hasil evaluasi pada siklus kedua sudah mencapai keberhasilan dengan kategori "Cukup Tinggi" dengan persentase hasil belajar siswa yang telah mencapai nilai KKM 70 sebesar $75 \%$ dan telah mencapai target ketuntasan yang telah ditetapkan. Berdasarkan hasil tersebut berarti hasil penelitian ini sudah mencapai indikator yang ditentukan yaitu $75 \%$ dan peneliti tidak melanjutkan penelitian ke siklus berikutnya.

Berikut ini merupakan prosesntase ketuntasan dan ketidaktuntasan hasil belajar siswa dari prasiklus, postes siklus I, dan postes siklus II pada mata pelajaran PAI dengan KKM 70.

Tabel 2. Ketuntasan Nilai Hasil Belajar

\begin{tabular}{ccc}
\hline Tes & Tercapai $(\%)$ & Tidak Tercapai $(\%)$ \\
\hline Pra Siklus & 38,09 & 61,90 \\
Akhir Siklus I & 66,67 & 33,33 \\
Akhir Siklus II & 90,47 & 9,52 \\
\hline
\end{tabular}

Berdasarkan tabel 2 di atas, dapat dilihat hasil peningkatan ketuntasan secara klasikal terjadi peningkatan hasil belajar dari prasiklus sebesar 38,09 ke siklus I sebesar 66,67\%. Dari siklus I ke siklus II mengalami peningkatan menjadi 90,47\%. Jadi, penerapan metode Problem Solving dinyatakan "Berhasil" karena sudah mencapai tingkat ketuntasan di atas $75 \%$ yaitu 90,47\%. Dengan demikian tampak bahwa penerapan pembelajaran Metode problem Solving dapat meningkatkan hasil belajar siswa pada mata pelajaran Pendidikan Agama Islam. Secara lebih jelas peningkatan tersebut tampak pada bagan di bawah ini. 
ISSN 1979-8598 E-ISSN: 2655-8378

http://journal.binadarma.ac.id/index.php/jurnalbinaedukasi

Vol. 13, No. 1, Juni 2020, 41 -- 51

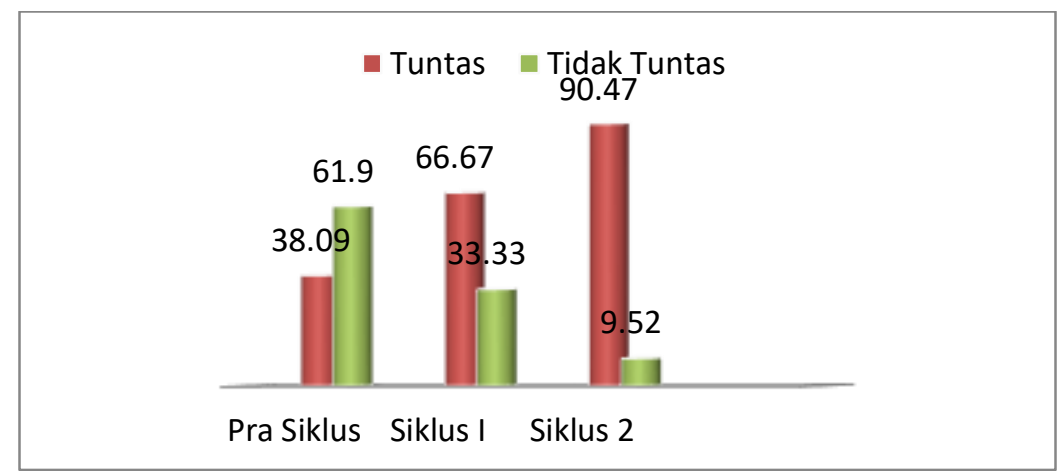

Gambar 3. Peningkatan Hasil Belajar Siswa dengan Metode Problem Solving

Pada bagan di atas menunjukkan bahwa nilai rata-rata yang dicapai sebagai hasil belajar siswa pada siklus II lebih tinggi dibanding siklus I demikian juga dengan ketuntasan klasikalnya. Dari data tabel tersebut terlihat perbandingan hasil belajar yang signifikan sebelum dan sesudah penerapan metode problem solving dalam pembelajaran Pendidikan Agama Islam.

Berdasarkan hasil penelitian, yaitu hasil dari nilai rata-rata pada pretes, kemudian postes di siklus I dan II disimpulkan bahwa penerapan metode problem solving memberikan dampak yang signifikan terhadap hasil belajar siswa. Hal tersebut terlihat dari persentase ketuntasan KKM pada siswa kelas VI dalam pelajaran Pendidikan Agama Islam. Peningkatan hasil belajar terjadi karena guru menerapkan metode problem solving dalam kegiatan pembelajaran di kelas.

\subsection{Pembahasan}

Peningkatan hasil belajar yang terjadi dikarenakan siswa lebih cepat mengingat materi pelajaran dengan penerapan pembelajaran model Metode Problem Solving. Proses pembelajaran disesuaikan dengan Rencana Pelaksanaan Pembelajaran (RPP) yang telah disusun sesuai dengan langkah-langkah metode problem solving. Siswa terlihat sangat terbantu dengan adanya model pembelajaran metode problem solving.

Dalam proses pembelajaran siswa dapat mendengar, melihat dan mencari sendiri jawaban dari permasalahan yang mereka hadapi yang akhirnya mereka dapat dengan mudah menyelesaikan permasalahan dan soal-soal yang diberikan dengan penerapan pembelajaran ini. Dalam proses pembelajaran ditemukan hal-hal sebagai berikut.

1. Siswa mulai berani mengemukakan pendapat pada kelompoknya karena merasa leluasa dalam berinteraksi.

2. Siswa menyampaikan gagasan yang bervariasi sehingga dalam penyelesaian masalah memerlukan waktu yang agak lama.

3. Siswa sudah terbiasa dengan model pembelajaran dengan menggunakan metode problem solving, sehingga pembelajaran berlangsung sesuai dengan rencana pembelajaran. 


\section{JURNAL ILMIAH \\ BINA EDUKASI \\ ISSN 1979-8598 E-ISSN: 2655-8378 \\ http://journal.binadarma.ac.id/index.php/jurnalbinaedukasi \\ Vol. 13, No. 1, Juni 2020, 41 -- 51}

\section{SIMPULAN}

Berdasarkan hasil penelitian dan pembahasan, dapat disimpulkan bahwa metode problem solving dapat meningkatkan hasil belajar Pendidikan Agama Islam siswa kelas VI SD Negeri 07 Indralaya Utara Kabupaten Ogan Ilir. Hasil penelitian menunjukkan hasil yang signifikasn dari pretes ke Siklus I dan II, yaitu dari 38,09\% ke 66,67\%, kemudian pada postes Siklus II sebesar 90,47\%. Pada Siklus II ketuntasan belajar sudah mencapai 75\% maka PTK cukup sampai dengan Siklus II.

Selain hasil belajar, penerapan metode problem solving juga meningkatkan motivasi belajar siswa, serta meningkatkan kemampuan siswa dalam berpikir kritis. Pada nilai-nilai karakter, penerapan metode problem solving juga meningkatkan sikap percaya diri, kerja sama, dan menghargai pada siswa.

Hasil penelitian ini diharapkan dapat memberikan pengetahuan dan pengalaman yang berharga bagi peneliti, guru, dan siswa. Peneliti lain juga dapat menerapkan metode ini pada mata pelajaran lain atau materi lain dalam pembelajaran Pendidikan Agama Islam. Dari penelitian ini, diharapkan guru kreatif dalam mendesain kegiatan belajar dengan menggunakan metode pembelajaran yang sesuai dengan materi dan kebutuhan siswa sehingga pembelajaran menjadi lebih bermakna. Pihak sekolah juga mendukung kegiatan belajar mengajar dengan menyediakan sarana dan prasarana belajar yang layak.

\section{DAFTAR PUSTAKA}

Apriadin, Muhammad. (2018). Penerapan Metode Problem Solving dalam Belajar Siswa Kelas VI pada Mata Pelajaran Fiqih di MI NW Dasan Agung Mataram. https://etheses.uinmataram.ac.id/1154/1/Muhammad\%20Apriadin151141198.pdf. Diunduh pada tanggal 14 Maret 2020.

Aqib, Zainal. (2009). Penelitian Tindakan Kelas. Bandung: CV. Yrama Widya.

Atmono, Dwi. (2009). Penelitian Tindakan Kelas. Kalimantan Selatan : Scripta Cendekia.

Fatimah, Siti. (2008). Modul Model-Model Pembelajaran SMP dan SMA. Palembang: Universitas Sriwijaya

Hamalik, Oemar. (2007). Proses Belajar Mengajar. Jakarta : Bumi Aksara.

Luqoni, Ahmad Fikri. (2018). Penerapan Metode Problem Solving untuk Meningkatkan Kompetensi Hasil Belajar Siswa pada Mata Pelajaran Fiqih di MtsN Pesanggaran Kabupaten Banyuwangi. Skripsi tidak dipublikasikan. Malang: Fakultas Ilmu Tarbiyah dan Keguruan, Universitas Islam Negeri Maulana Malik Ibrahim.

Maftuhatun, Ratna. (2016). Metode Problem Solving dalam Pembelajaran PAI di SD Muhammadiyah Demangan Yogyakarta. http://digilib.uin-suka.ac.id/.pdf. Diunduh pada tanggal 23 Maret 2020. 


\section{JURNAL ILMIAH}

BINA EDUKASI

ISSN 1979-8598 E-ISSN: 2655-8378

http://journal.binadarma.ac.id/index.php/jurnalbinaedukasi

Vol. 13, No. 1, Juni 2020, 41 -- 51

Misbahudin. (2018). Pembelajaran Pendidikan Agama Islam dengan Metode Problem Solving Untuk Meningkatkan Prestasi Belajar Siswa (Studi Multi Kasus di SMP Negeri 1 Pogalan dan SMP Negeri 2 Pogalan Trenggalek). http://repo.iain-tulungagung.ac.id/7114/. Diunduh pada tanggal 10 April 2020.

Rahim, dkk. (2001). Metodologi Pendidikan Agama Islam. Jakarta : Departemen Agama.

Soedarsono, FX. (2001). Pedoman Pelaksanaan Penelitian Tindakan Kelas. Jakarta: Raja Grafindo Persada.

Sudjana, Nana. (2010). Metode Statistika. Bandung: Transito.

Sukardi. (2007). Metodologi Penelitian Pendidikan. Yogyakarta: Bumi Aksara.

Tafsir, Ahmad. (1992). Ilmu Pendidikan dalam Persfektif Islam. Bandung : Rosda Karya. 